\title{
Characterization of Selected Honey in South- East Nigeria: Theoretical Translation
}

\author{
Nwoko C. I. A. ${ }^{1}$, Nkwoada A.U ${ }^{2}$, Ubeh E.O ${ }^{3}$, Njoku A. ${ }^{4}$ \\ ${ }^{1,2,4}$ Department of Chemistry, Federal University of Technology Owerri \\ Corresponding Author: nwokochristopher@yahoo.com \\ ${ }^{3}$ Department of Agricultural Extension, Federal University of Technology Owerri
}

\begin{abstract}
With the vast honey bee species producing honey for international export and consumption in Nigeria, there is need for theoretical translation of quality assessment and characterization of honey for human consumption. The physicochemical and mineral contents of some selected honey in the five South east geopolitical states of Nigeria was performed for above mentioned application. The results were evaluated with $3 D$ plot to identify the statistical significance of the parameters analyzed. The levels of glucose and fructose were accepted by codex alimentation standard and rejected samples $B, C$, and $G$. A correlation of similar botanical origin was demonstrated in sample $B, C$ and $G$ and similarly observed in their moisture content been > $21 \%$. The $p H$ and electrical conductivity showed no significant variation. The codex hydroxyl methyl furfural standard identified samples $B, E$ and L to be "aged honey" or falsified honey in circulation. The $3 D$ plot showed the significant variation of hydroxyl methyl furfural content of samples. A hypothesis was observed when the samples and previously analyzed Nigerian samples were compared; metal concentration levels of Group 1 elements > Group 2 > Transition metals in Nigerian honey and formed an identification trend.
\end{abstract}

Keywords-Honey, bees, honeybees characterization, consumption.

\section{INTRODUCTION}

For centuries, honey has been known for its potent activity against antibiotic resistant bacteria and as a potential source of antimicrobial compounds $[1,2]$. As previously reported, the typical constituents of honey by dry matter is sugar, with small amounts of about 22 additional complex sugars and other constituents like pigments, acids and minerals that bring about unique honey types. Subsequently, honeybees are related to the identity and quality of their honey, however, there are not many studies that establish the stability of chemical compounds present in honey and ensuring that honey consumption are devoid of toxic compounds for human health [3, 4].

A study conducted on stability of Nigerian honey showed that if natural harvested honeys are produced hygienically and stored, that its stability can be up to 2 years [5], while the geographical and botanical origin of the flora, type and activity of the bee can also affect the quality and honey composition [6]. Nevertheless, the beehive type does not affect their physicochemical properties [7]. Thus promoting honey with information on its characterization [8] has opened avenues for local products (exports) to meet international standards $[9,10]$. Hence, it created the need for legislation on honey quality given the vast bee species in existence [11, 12]. Studies on the proximate analysis and mineral contents of honey for different countries, have confirmed the presence of trace metals such as $\mathrm{Fe}, \mathrm{Al}, \mathrm{Mn}, \mathrm{Mg}, \mathrm{Na}, \mathrm{K}, \mathrm{Cu}$ and $\mathrm{Ca}[13,14,15]$. These exist in some form of natural combination which can be used as nutritional supplement for humans [16]. Yet, despite the compositional and nutritional value of honey bees, comparative relationship data between the nutritional components and biochemical composition of the vast honey species are limited in Nigeria [17].More over studies have shown that certain commercial honey has higher levels of some parameters which suggested some kind of adulteration [18] or poor hygiene and handling [19]. Hence, this research work will study statistical application and theoretical translation on characterization of selected honey in south-east Nigeria of some selected honey in the five South east geopolitical states of Nigeria to establish their quality for human consumption.

\section{MATERIALS AND METHOD}

\section{Collection of samples}

The samples were purchased from 12 pre-named locations in Abia State, Imo State, Enugu State, Ebonyi State and Anambra State of Nigeria. They samples collected were tagged (A, B, C, D, E, F, G, H, I, J, K, L) for easy identification. The collected samples were placed inside plastic bottles of $250 \mathrm{ml}$ each and tightly sealed and tagged. Afterwards the sample bottle was labeled with sample volume, date, location, time of collection and stored at 4 OC prior to analysis. Honey sample was obtained from National Root Crop and Research Institute Umudike in 
Nigeria (NRCRI) known for honey and bee keeping production and research..

\section{Physicochemical analysis}

The physicochemical characteristics of honey are a routine laboratory analysis. It provides quantitative results and allows for approximate estimation of the presence of honey blend. The study was carefully carried out using recently reported approach [20]. The moisture content was determined using a digital refractometer calibrated with double distilled water. Ash content was measured with reported AOAC method in previous study [20]. Hanna Instrument (HI 98127) was used to determine $\mathrm{pH}$ of the prepared solution while Hanna Instrument (HI 98311) was used for electrical conductivity of the prepared solution. Milli-Q water was used for preparing honey solution for Hanna Instruments. For quality assurance, we ran each experiment 4 times and reported only the average of the quadruple values.

To determine the Hydroxymethylfurfural (HMF); $5 \mathrm{~g}$ of honey was dissolved in $25 \mathrm{~mL}$ of distilled water. The absorbance was measured at 284 and $336 \mathrm{~nm}$ against a filtered solution treated with NaHSO3. The HMF value were then determined using the following the equation below $[10,12]$. Where $\mathrm{D}=$ dilution factor and $\mathrm{W}=$ sample weight in grams:

$\mathrm{HMF}(\mathrm{mg} / \mathrm{kg}$ of honey $)=\left(\mathrm{Abs}_{284}-\mathrm{Abs}_{336}\right) \mathrm{X} 149.7 \mathrm{X} 5 \mathrm{X}$ $\mathrm{D} / \mathrm{W}$.

\section{Metal assay}

The metal contents were determined using commonly reported standard AOAC method [6]. This was carried out by measuring $5 \mathrm{ml}$ of $10 \% \mathrm{HCl}$ solution and added to the ash and warmed in a water bath to dissolve. $5 \mathrm{ml}$ of $10 \%$ Trioxonitrate (v) acid was further added and warming continued until total dissolution in the water bath. A stirring rod was used to transfer the solution into a funnel then to a clean dry $50 \mathrm{ml}$ standard volumetric flask. The "ashed" solution was analyzed for $\mathrm{Ca}, \mathrm{Mg}, \mathrm{Fe}, \mathrm{K}, \mathrm{Zn}, \mathrm{Pb}$ and $\mathrm{Cd}$ by direct aspiration via atomic absorption spectrophotometer (AAS).

\section{Determination of sugars}

$1.0 \mathrm{~g}$ of honey sample was weighed into a graduated $100 \mathrm{ml}$ cylinder. $10 \mathrm{ml}$ of distilled water was added to the sample and stirred with a long glass rod. $13 \mathrm{ml} 52 \%$ perchloric acid reagent was further added and stirred for 20 minutes. The content was filtered into $25 \mathrm{ml}$ graduated flask and diluted to full mark with distilled water. $10 \mathrm{ml}$ of the sample extract was diluted to $100 \mathrm{ml}$ with distilled water, and then $1 \mathrm{ml}$ of the dilute filtrate was transferred into a test tube. Blanks were also prepared using double distilled water. The standards of the different sugars (glucose, fructose and sucrose) were prepared using $1 \mathrm{ml}$ of each. $5 \mathrm{ml}$ of freshly prepared anthrone reagent was added rapidly and the tubes closed to allow for mixing of the contents. They solution was then placed in water-bath for 12 minutes and allowed to cool at room temperature to read the absorbance at $630 \mathrm{~nm}$ against the blanks [21]. Results were calculated on the following formulae:

$\%$ glucose, fructose or sucrose $=(25 \times \mathrm{X}) /(\mathrm{S} \mathrm{X} \mathrm{W})$

Where $\mathrm{H}=$ Absorbance of dilute honey sample

$\mathrm{S}=$ Absorbance of dilute standard

$\mathrm{W}=$ Weight of sample used

\section{RESULTS AND DISCUSSION}

\section{Physicochemical and sugar analyses}

The result for determination of composite sugars (fructose, glucose and sucrose) is as shown in Table 1. Observation showed that the monosaccharide's (glucose and fructose) and the disaccharide (sucrose) in the all 12 samples make up $70 \%$ composition of each honey sample respectively. Sample A and E had the highest fructose content, sample $\mathrm{C}$ and $\mathrm{E}$ showed the highest glucose value while samples $\mathrm{B}$ $\mathrm{C}$ and $\mathrm{G}$ gave the highest sucrose content. They result confirmed good storage conditions for the samples that had sugar concentrations above $70 \%$ except samples B, H, J, and L. They conditions are often reflected in the stability of the honey products. Thus, the formation of undesirable products like 2-acetylfuran, Isomaltol and hydroxy-2methyl-5-6-didropiran-4-one that can cause change in color, odor and taste of honey are prevented. [3].

Observation shows that the concentration of glucose, fructose and sucrose varies, as well as the ratio between them. This useful indicator [3] showed the classification of the honey samples based on geographical origin and botanical origin as using their ratios. Samples A and E are of same botanical origin, Samples D, F and $\mathrm{H}$ are of same botanical origin, samples $\mathrm{B}, \mathrm{C}$, and $\mathrm{G}$ are of similar geographical origin while samples I, J, K and L are same geographical origin.

On the other hand, the results indicated that glucose and fructose are the main composition of the honey samples and corresponds to Codex Alimentations commission international standard [22]. The higher levels of sucrose in samples B, C and G could be an indication of adulteration or early harvesting as seen in Table 1 . Thus these formed a correlation with the botanical origin based classification of samples using their ratios. However, in samples A, D, F and $\mathrm{H}$, the glucose content were below $5 \%$. This showed the natural feeding of the honey bees and high quality of the honey produced from the farms [20]. The results were further compared with previous published results (sugars in honey) for honey samples in Nigeria [5, 18, 23, 24]. The results showed no significant difference from previous studies.

The codex alimentarius committee on sugars recommended moisture content should not exceed $20 \mathrm{~g}$ $100 \mathrm{~g}-1$ [22]. The samples analyzed were all within $16 \%$ to 
$20.7 \%$ except samples $\mathrm{B}, \mathrm{C}$ and $\mathrm{G}$ greater than $21 \%$. However, research has shown that moisture content in honey samples lower than $20 \%$ elongates the shelf life of honey [20], while factors of temperature and relative humidity in the geographical origin affects honey moisture content. Therefore all samples showed no significant difference with samples in the south east region of Nigeria $[16,17]$ and were within $17 \%$ to $21 \%$. While samples from the North were lower in moisture content about $15 \%$ to $18 \%$ when compared to previous results in Nigeria $[4,6]$. There was no significance difference between the samples in $\mathrm{pH}$ and electrical conductivity while the ash content showed variation

The $\mathrm{pH}$ values of the twelve honey samples were measured and the obtained results confirmed that, all tested samples were acidic ( $\mathrm{pH} 3.0-4.2$ ) as seen in Table 2 and within the standard limit of Codex Alimentatarius value of $\mathrm{pH}$ 3.40-6.10 [22] except sample D and F. However they were all close to previously reported values in Nigeria [5, 6, 16, and 21].

The higher the ash content, the higher the electrical conductivity. This showed a linear relationship with the both ash content and electrical conductivity and similarly had been observed by research [20]. All samples were below the standard electrical conductivity limit of $0.8 \mathrm{mS} / \mathrm{cm}$ recommended by codex alimentatarius [22]. The Ash content of 6 samples (B, C, E, G, J \& L) were within the acceptable range $(0.6-1.2 \mathrm{~g} / 100 \mathrm{~g})$, while samples (A, D, F, H, I \& K) were not accepted by codex range Codex Alimentations. This disparity could be an indication of the honey colonies fed with sugar syrup that had lower ash [20]. The codex HMF standard [22] for honey is recommended at maximum $40 \mathrm{mgkg}-1$ for processed honey and $80 \mathrm{mgkg}-1$ for declared tropical origins. Thus all honey samples met the standard but samples $\mathrm{B}, \mathrm{E}$ and $\mathrm{L}$ were not accepted by codex alimentations. This identified samples (A, D, F, H) to be fresh honey samples, samples (C, G, I, J) were not fresh while sample (B, E and L) were either "aged honey" or falsified honey. This can be obtained by adding invert syrup since 5-HMF can be produced to the inversion of sucrose by heated sugars in the presence of an acid. [3]

\section{Metal Assay}

Studies have shown that the mineral content in honey ranges from $0.04 \%$ in light honeys to $0.2 \%$ in dark honeys. In addition, the chemical components reflect the type of soil from which both the plant and nectar were obtained [3].From Table 1, the mineral concentration of calcium was the highest in all the 12 samples followed by magnesium with similar concentration levels. The concentrations of lead and cadmium were all below the jointly proposed acceptable levels of $25 \mu \mathrm{g} k \mathrm{~kg}-1$ for $\mathrm{Pb}^{2+}$ and $7 \mu \mathrm{g} \mathrm{kg}-1$ for $\mathrm{Cd}^{2+}$ by world health organization (WHO) and the Food and Agricultural organization (FAO) [25]. The remaining elements $\mathrm{Fe}^{2+}, \mathrm{K}^{+}, \mathrm{Zn}^{2+}$, were all below $0.7 \mathrm{mg} / \mathrm{l}$. These reflected the botanical origin of the studied honey samples and formed a correlation that south east Nigerian honey are similar to Hungarian Linden honey based on mineral content [26].The samples D, E and F obtained from Owerri urban in Imo-state were compared with previous results from Owerri urban [18]. A correlation was seen with $\mathrm{Pb}^{2+}$ been very negligible, $\mathrm{Fe}^{2+}$ in very small concentration, while $\mathrm{K}^{+}, \mathrm{Mg}^{2+}$ and $\mathrm{Ca}^{2+}$ were of higher concentration levels [18]. Thus our result was in agreement with the study that reported samples in Owerri as having the least occurrence of metals. Furthermore, obtained information (data) in all the honey samples of Nigeria as analyzed by previous researchers showed the following hypothesis; the metal concentration levels of Group 1 elements > Group $2>$ Transition metals in Nigerian honey $[6,16,17,18$, ] and may form an identification. (though we only analyzed $\mathrm{K}^{+}$in group 1 )

\section{D Plot}

The results from the 3D plot can be seen below in fig1. The variations of HMF concentration could be observed at Anambra, Imo and Abia in fig 1A. In Addition, pH, electrical conductivity, ash content and, moisture content were uniformly distributed within the 12 sampling points. The fig $1 \mathrm{~B}$ depicts the concentrations of heavy metals in the 12 sampling locations. Magnesium and calcium concentrations can be clearly identified as having concentrations greater than $1.0 \mathrm{mg} / \mathrm{l}$ but less than 2.50 $\mathrm{mg} / \mathrm{l}$ each. The concentration of potassium can also be seen with variations in all the sample locations e.g., it had the lowest points at Ebonyi state with $0.07 \mathrm{mg} / \mathrm{l}$ and 0.06 $\mathrm{mg} / \mathrm{l}$ and shown as a flat bar respectively.

\section{CONCLUSION}

Samples A and E had the highest fructose content, sample $\mathrm{C}$ and $\mathrm{E}$ showed the highest glucose value while samples B $\mathrm{C}$ and $\mathrm{G}$ gave the highest sucrose content. The results also confirmed that the honey samples can be classified based on geographical origin and botanical origin. All honey samples were moderately acidic while the moisture content was highest in B, C and $\mathrm{G}$ and $\mathrm{L}$. codex alimentations identified samples (A, D, F, H) to be fresh honey samples, samples (C, G, I, J) were not fresh while sample (B, E and L) were either "aged honey" or falsified honey. The mineral content of the were within world health organization (WHO)/(FAO) recommendations. The following identification trend was observed to exist; the metal concentration levels of Group 1 elements > Group 2 $>$ Transition metals in Nigerian honey. 


\section{REFERENCES}

[1] Kwakman, H. S.P., and Zaat, S.A.J. (2012). Antibacterial Components of Honey. IUBMB Life, 64 (1), 48-55. doi:10.1002/iub.578.

[2] Mahendran, S., and Kumarasamy, D. (2015). Antimicrobial activity of some honey samples against pathogenic bacteria. International Letters of Natural Sciences, 34 , 15-20. doi:10.18052/www.scipress.com/ILNS.34.15.

[3] Missio da Silva, P., Gauche, C., Gonzaga, L.V., Costa, O.C.A., and Fett, R. (2016). Honey: Chemical composition, stability and authenticity. Food Chemistry, 196, 309-323. doi.org/10.1016/j.foodchem.2015.09.051.

[4] Buba, F., Gidado, A., and Shugaba, A. (2013). Analysis of Biochemical Composition of Honey Samples from North-East Nigeria. Biochemistry \&Analytical Biochemistry, 2 (139). doi: 10.4172/2161-1009.1000139.

[5] Fasasi, K.A. (2012). Physicochemical attributes of Nigerian natural honey from honey bees (Apismelliferaadansonii) (Hymenoptera: Apidae) and its shelf life in storage at oom temperature. Pakistani Journal of Biological sciences, 15 (21), 1027-1033. doi: 10.3923/pjbs.2012.1027.1033.

[6] Ndife, J, Kida, F., and Makarfi,T. (2014). Quality assessment of Nigerian honeys sourced from different floral locations.Journal of Food and Nutrition Sciences. 2 (4), 162-167. doi: 10.11648/j.jfns.20140204.20.

[7] Nyau, V., Mwanza, E.P., and Moonga, H.B. (2013). Physico-chemical qualities of honey harvested from different beehive types in zambia. African journal of food, agriculture, nutrition and development, 13 (2).

[8] Bogdanov, S., Ruoff, K., and Oddo, L.P. (2004). Physico-chemical methods for the characterisation of unifloral honeys: A review. Apidologie 35, S4-S17. doi: 10.1051/apido:2004047.

[9] Mondragón-Cortez , P., Ulloa, J.A., Rosas-Ulloa, P., Rodríguez-Rodríguez, R., and Resendiz Vázquez, J.A., (2013). Physicochemical characterization of honey from the West region of México, CyTA - Journal of Food,11(1), 7-13. doi: 10.1080/19476337.2012.673175.

[10] Almeida-Muradian, L.B., Stramm, K.M., Horita, A., Barth, M.O., Freitas, S.A., and Leticia M. Estevinho, L.M. (2013).Comparative study of the physicochemical and palynological characteristics of honey from Meliponasubnitida and Apismellifera. International Journal of Food Science and Technology, 48, 16981706. doi:10.1111/ijfs.12140.

[11] Awada, M.H., and Elgornazi, A.M. (2016). Physicochemical characterization of honey from KasrKhiar and Garaboliareas-Libya. Asian Journal of Plant Science and Research, 6 (1), 8-12.
[12] Nascimento, A.S., Marchini, L.C., Lopes de Carvalho, C.A., Dias -Araújo, F.D., Alves de Olinda, R., and Antonia da Silveira, T. (2015). Physical-Chemical Parameters of Honey of Stingless Bee (Hymenoptera: Apidae). American Chemical Science Journal, 7 (3),139-149. doi: 10.9734/ACSj/2015/17547.

[13] Cantarelli, M.A., Pellerano, R.G., Marchevsky, E.J.,and Camiña, J.M. (2008). quality of honey from argentina: study of chemical composition and trace elements. The Journal of the Argentine Chemical Society, 96 (1-2), 33-41.

[14] Kambai, C., Popoola, V., Ugbe, C.J., Janfa, N., and Ukanyirioha, C. (2015). Proximate and Mineral Elements Composition of Honey from Selected Hives in Jos Metropolis, Nigeria. IOSR Journal of Environmental Science, Toxicology and Food Technology, 9 (9), 94-98. doi: 10.9790/240209919498.

[15] Bogdanov, S., Haldimann, M., Luginbühl, W., and Gallmann, P. (2007). Minerals in honey: environmental, geographical and botanical aspects. Journal of Apicultural Research and Bee World 46 (4), 269-275.

[16] Oyeyemi, S.D., Kayode, J., and Owolabi, M.O. (2015). Comparative Nutritional Studies on Honey Samples in Ado Ekiti, Ekiti State, Nigeria. Donnish Journal of Medicinal Plant Research, 2 (2) 16-20.

[17] Adeniyi, K. A., Daudu, O. A. Y., Abubakar, A., Ismail, A. D., Busari, M. B., Abdulsalami, H., and OyiboUsman, K. A. (2014). Comparative analysis of the proximate and nutritional compositions of Nigerian Bitter and Serve Honey from ApisMellifera. International Journal of Scientific and Research Publications, 4 (11), 1-4.

[18] Agbagwa, O. E., Otokunefor, T.V., and FrankPeterside, N. (2011). Quality assessment of Nigeria honey and manuka honey. Journal of Microbiology and Biotechnology Research, 1 (3), 20-31.

[19] Oshomah, M.U, (2014). Microbiological Evaluation of Commercial Honey from Edo State, Nigeria . International Journal of Scientific \& Engineering Research, 5 (12), 796-799.

[20] Sohaimy, S.A., El, S.H., Masry, B., and Shehata, M.G. (2015). Physicochemical characteristics of honey from different origins. Annals of Agricultural Science . 60 (2), 279-287. doi.org/10.1016/j.aoas.2015.10.015.

[21] Agbagwa,O.C., and Otukanefor, T.V. (2011). Quality Assessment of Nigerian honey and Manuka Honey. Journal of Microbiology And Biotechnology Research, 1 (3), 20-31.

[22] Codex Alimentations, (2001). Draft revised standard for standard for honey (at step 10 of the codex procedure). Alinorm 01 (25), 19-26. 
[23] Buba, F., Gidado, A., and Shugaba, A. (2013). Analysis of Biochemical Compositionof Honey Samples from North-East Nigeria. Biochem Anal Biochem, 2 (139). doi:10.4172/2161-1009.1000139.

[24] James, O.O., Mesubi, M.A., Usman, L.A., Yeye, S.O., Ajanaku, K.O., Ogunniran, K.O., Ajani, O.O, and Siyanbola, T.O. (2009). Physical characterisation of some honey samples fromNorth-Central Nigeria. International Journal of Physical Sciences 4 (9), 464470 .
[25] Alqarni, A. S., Owayss, A. A., and Mahmoud, A. A. (2012). Mineral content and physicalproperties of local and imported honeys in Saudi Arabia. Journal of SaudiChemical Society, 5, 618-625.

[26] Ajtony, Z., Bencs, L., Haraszi, R., Szigeti, J., and Szoboszlai, N. (2007). Study on the simultaneous determination of some essential and toxic trace elements in honey by multi-element graphite furnace atomic absorption spectrometry. Talanta, 71, 683-690.

Table.1: Physicochemical parameters of honey from 5 south-eastern states in Nigeria

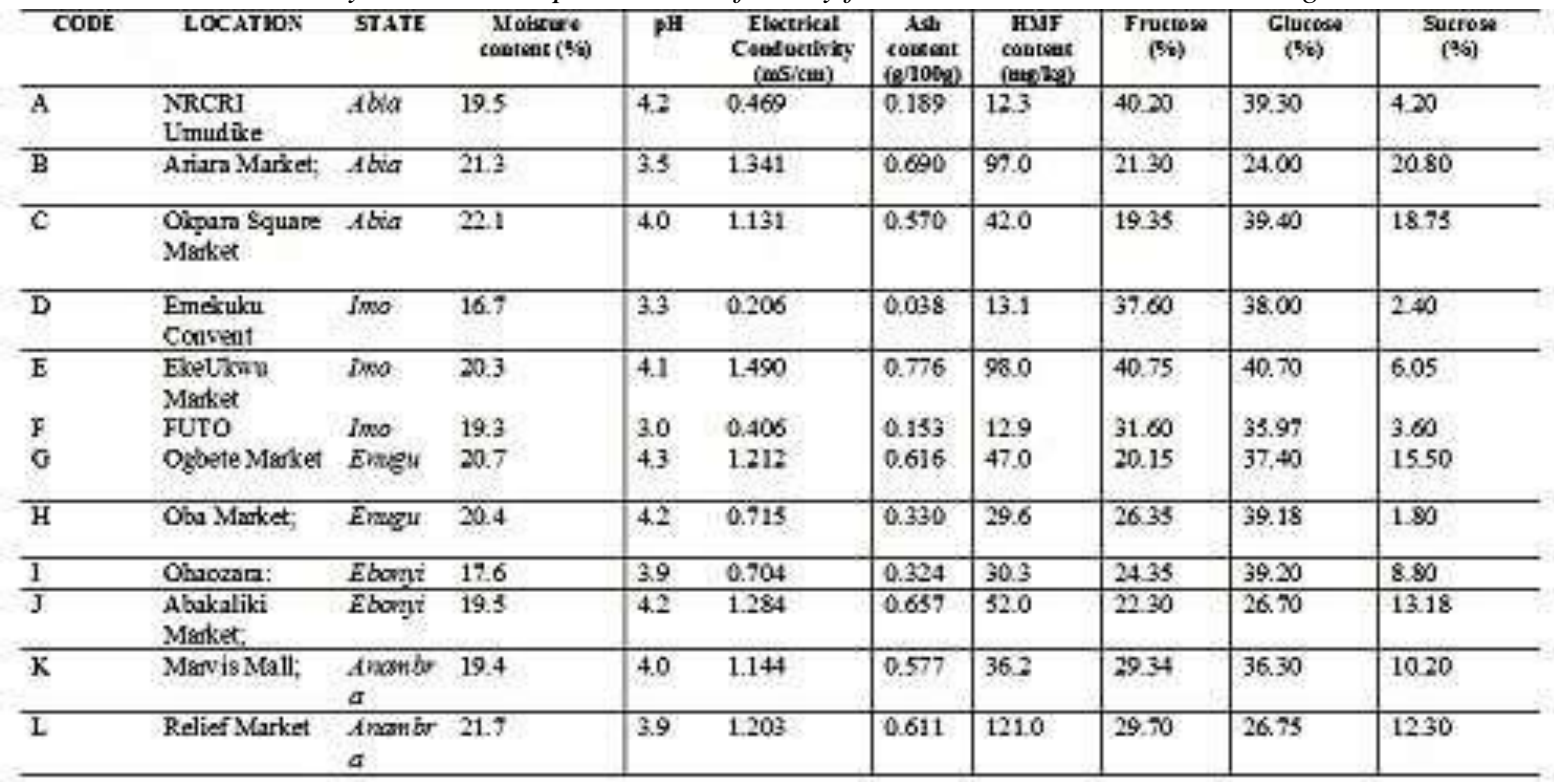

Table.2: Mineral composition of honey samples from 5 south-eastern states in Nigeria

\begin{tabular}{|c|c|c|c|c|c|c|c|c|c|}
\hline CODE & LOCATION & STATE & $\begin{array}{l}\mathrm{Ca}^{2+} \\
(\mathrm{mg} /)\end{array}$ & $\begin{array}{c}\mathrm{Mg}^{2+} \\
(\mathrm{mg} / \mathrm{l})\end{array}$ & $\begin{array}{c}\mathrm{Fe}^{2+} \\
(\mathrm{mg} /)\end{array}$ & $\underset{(\mathrm{mg} / \mathrm{l})}{\mathbf{K}^{+}}$ & $\begin{array}{c}\mathrm{Zn}^{2+} \\
(\mathrm{mg} / \mathrm{l})\end{array}$ & $\begin{array}{c}\mathrm{Pb}^{{ }^{+}} \\
(\mathrm{mg} / \mathrm{l})\end{array}$ & $\begin{array}{c}\mathrm{Cd}^{1+} \\
(\mathrm{mg} /)\end{array}$ \\
\hline A & NRCRI Umudike & Abia & 2.29 & 1.07 & 0.06 & 0.44 & 0.05 & Nil & Nil \\
\hline B & Ariara Market, & Abia & 1.47 & 1.15 & 0.07 & 0.58 & 0.20 & 0.01 & Nil \\
\hline C & Okpara Square Market & Abia & 1.54 & 1.00 & 0.05 & 0.53 & 0.08 & Nil & Nil \\
\hline D & Emekuku Convent & Imo & 2.17 & 0.94 & 0.05 & 0.41 & 0.04 & Nil & Nil \\
\hline E & EkeUkwu Market & Imo & 1.42 & 0.97 & 0.03 & 0.58 & 0.10 & 0.02 & Nil \\
\hline F & FUTO & Imo & 2.04 & 1.05 & 0.04 & 0.50 & 0.07 & Nil & Nil \\
\hline G & Ogbete Market & Enugu & 1.35 & 1.09 & 0.03 & 0.65 & 0.11 & 0.01 & Nil \\
\hline $\mathrm{H}$ & Oba Market; & Enugu & 1.67 & 1.02 & 0.04 & 0.50 & 0.07 & Nil & Níl \\
\hline I & IshieluOhaozara: & Ebonyi & 1.69 & 1.03 & 0.02 & 0.07 & 0.13 & Nil & Nil \\
\hline $\mathrm{J}$ & Abakaliki Market; & Ebonyi & 1.66 & 1.02 & 0.06 & 0.06 & 0.09 & Nil & Nil \\
\hline $\mathrm{K}$ & Marvis Mall A wka; & Anconbra & 1.58 & 1.20 & 0.06 & 0.42 & 0.08 & Nil & Nil \\
\hline L & Relief Market & Anconbra & 1.30 & 1.09 & 0.03 & 0.63 & 0.12 & 0.01 & Nil \\
\hline
\end{tabular}




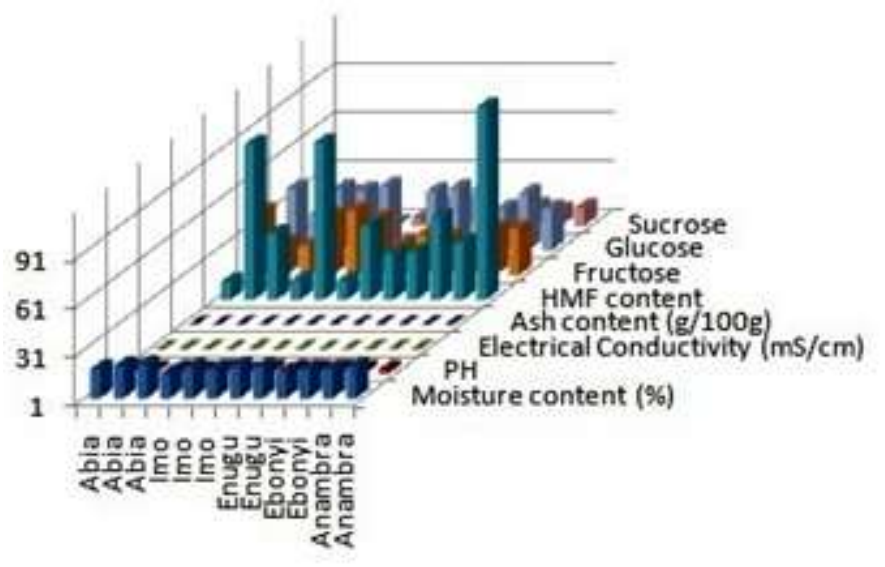

A

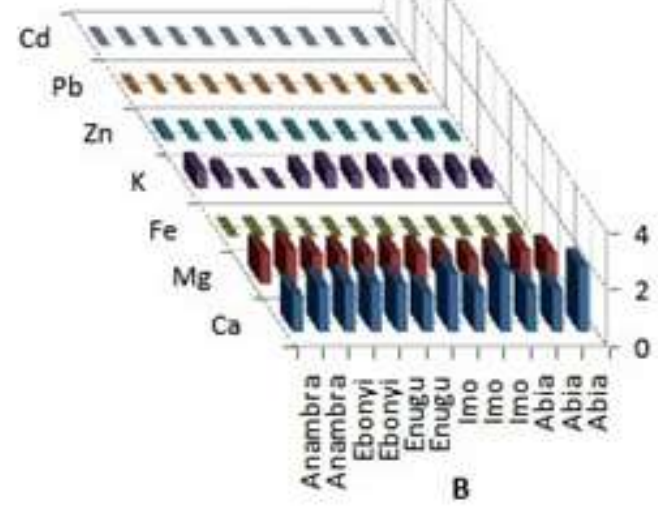

$\mathrm{Cd}$

in 20202020

K Povoresere

Fig.1: (1A): The physicochemical parameters of honey from 12 sample points; $1(B)$ : The heavy metal concentration of the honey samples 